\title{
A Case Study on Preservice Primary School Teachers' Flower Care at School within the Scope of Community Service Practices Course
}

\author{
Zeynep Dogan ${ }^{1, *}$ \\ ${ }^{1}$ Department of Primary Education, Yildiz Technical University, Istanbul, Turkey \\ *Correspondence: Faculty of Education, Yildiz Technical University, A-312, Davutpasa Campus, Esenler, Istanbul, \\ Turkey. Tel: 90-212-383-4856. E-mail: zeynepyildiz.2005@hotmail.com
}

Received: January 2, 2019

Accepted: February 9, 2019 Online Published: February 20, 2019

doi:10.5430/wje.v9n1p172

URL: https://doi.org/10.5430/wje.v9n1p172

\begin{abstract}
The aim of this study is to present the details of a practice that is carried out within the scope of Community Service Practices Course from a scientific perspective. And also to investigate the views of the pre-service teachers related to the topic. Research design is determined as a case study method. For the data collection, interview method was used from qualitative data collection methods. The sample is composed of 8 pre-service primary school teachers. Within the relevant course, a potted flower to be determined by the pre-service teachers was planted in a pot in a suitable place in the faculty, and the students were given the task of undertaking all kinds of care for the flower during the semester. Semi-structured interviews with the pre-service teachers were held at the end of the term and their opinions were taken. According to the results, all of the pre-service teachers find the implementation useful and important for their teaching career. They stated that they got information about flower care, they gained awareness and they were impressed affectively.
\end{abstract}

Keywords: primary school teaching, community service practices course, flower care

\section{Introduction}

The environment can be defined as a system in which living things such as human beings, animals, plants, and non-living things such as air, water and soil come together and interact with one another (Environmental Law, 1983). The theme of nature includes reciprocal relations and interactions of human with other human beings, non-human creatures and non-living things outside the living world (Keles et. al., 2009). In this respect, environment involves all biological, physical, social, economic and cultural conditions surrounding living things and influencing them in many aspects (Environmental Law, 1983).

Environmental awareness involves individuals' knowledge of the environment related problems and the solutions to these problems, individual's positive attitudes towards the environment such as the value judgments related to environmental problems and the readiness to solve environmental problems, individuals' beneficial behaviors to protect the environment, such as compromising self-interest for protection of the environment, reducing environmental problems or contributing to the elimination of these problems (De Haan, 1996 as cited in Erten, 2012). It is acknowledged that education is very instrumental and an essential agent in national development. As a result, improving the quality of education, especially at the basic education level, has become the concern of all nations (Esia-Donkoh \& Baffoe, 2018). It is thought that the education process which is spent in the formation of environmental consciousness has the most important share in the individual. At this point, the teachers carrying out this process incur responsibilities. Although a course related to environmental education is offered in our country in the primary school teaching department in undergraduate program, it is seen that this course is based on the theoretical dimension of the subject and it does not show an approach to environmental awareness from an affective perspective. Higher education is a service provider that will produce qualified human resources (Astuti et al., 2016). It is thought that within the scope of primary school teaching program, which is currently carried out in the faculties of education, the Community Service Practices Course can be utilized in order to bring sustainable environmental awareness to pre-service teachers. The origins of Community Service Practices are based on 1870s and the philosophical and psychological fundamentals of Community Service Practices are based on the views of John Dewey which he mentioned at the beginning of the 1900's (Hatcher \& Erasmus, 2008; Titlebaum et al., 2004). The "Community 
Service" concept was first used in the United States in 1966 as a term. The first event in which the relationship between school and community service practice was established was the "Atlanta Community Service Conference" in 1969. In 1979, Sigmon built the conceptual framework of Community Service Practices on three fundamental principles. These are "The one who gets service controls the service provider", "The one who gets service both provides better service and gets better service as a result of what she/he does" and "The one who provides service both learns and checks his/her learning expectations to a considerable extent" (Titlebaum et al., 2004).

In our country, in the new teacher training program being applied starting from the academic year of 2006-2007, it is adopted that the view that emphasis should be given to lectures for practical as well as theoretical courses and in this sense it is decided to add the Community Service Practices Course to the new program curriculum (Elma et al., 2010). It is aimed to support the skills of social sensitivity and awareness, cooperation, solidarity, effective communication and self-evaluation and to create the sense of social responsibility and self-confidence. Identifying the current problems of the community and preparing projects for solving them, taking part in social responsibility projects on a voluntary basis, and acquiring basic knowledge and skills for the implementation of community service activities in schools can be listed as the importance of community service practices. In this respect, it is seen that the pre-service teachers have an important position in creating a sustainable environmental awareness in our society.

With this study, it is aimed to transfer the knowledge of the pre-service teachers obtained during the implementation period to the future generations and to the students in the educational institutions where they work during their profession and the students who carry out the educational activities. In this respect, the purpose of this study is to present the details of an implementation from a scientific perspective in the context of Community Service Practices course which is one of the courses in the third year curriculum of the primary school teaching department in undergraduate program. Another aim is to investigate pre-service teachers' opinions about the topic.

\section{Method}

\subsection{Research Design}

The research design was determined as a case study. According to Yildirim and Simsek (2011), case study is a research method that allows a researcher to examine a phenomenon or case in details that cannot be controlled based on the questions of how and why. In this study, research design was designated as a case study since it included the detailed examination of the pre-service teachers' views.

\subsection{Sample}

The sample of the research was composed of 8 pre-service teachers who are studying in the 3rd grade of primary school teaching department. There were 3 girls and 5 boys participants. It was the first time for them to take community service practices course and they participated in the study voluntarily.

\subsection{Implementation}

In the study, pre-service teachers were asked to plant a potted flower in a pot and to put it in a suitable place in the faculty and also they were told that they were responsible for all kinds of flower care of their own flowers during the term within the scope of relevant course. Preservice teachers for this task have been given 10 weeks. Regarding the task assigned, guidelines had been drawn up and pre-service teachers were required to perform their work by following these directives within 10 weeks. The guidelines to be followed within the course of community service practices were expressed to pre-service teachers as follows:

1. The pot will be at least $30 \mathrm{~cm}$ in height and 20 liters in volume (Smaller ones may be dangerous such as falling from the railing)

2. You will find a suitable flower by yourself for the faculty. (Everyone will set a different flower, so be in touch with each other so you cannot choose the same flower as your friend.)

3. Your choice will not be flower seeds, it will be in the form of seedlings, there will not be seasonal flowers

4. On the pots, "care of flower has been undertaken under the guidance of Dr. Zeynep DOGAN within the scope of Community Service Practices course" will be written on A4 papers and pasted.

5. A video will be recorded and it will not last more than 2 minutes. The video will include buying a pot and the other materials, planting the flower and locating it in an appropriate place.

6. Flower care and watering will be regularly carried out within necessary time intervals. 
7. Each week the report about the state of the flower (size, leaf, flower, etc.) will be kept and photographed and added to the report. Your term-end report under this article should include 9 weeks of data. (You can send the report by e-mail at the end of the semester)

8. The study can be carried out by spending approximately $20 \mathrm{TL}$. If it will force you in the material sense, the expenses will be covered by me. In order to be cheaper, you can make your purchases from large construction markets, cheap markets, discount markets or from the internet.

\subsection{Data Collection Instrument}

Within the scope of the research, semi-structured interview forms were formed to determine the views of the pre-service teachers related to the research process. In these forms, there are questions about the implementation. These questions were first created by the researcher, and afterwards the opinions of the related experts were taken and finalized after the necessary corrections. In the last version of interview form consists of 13 questions including the categories of previous experience, implementation process, education and evaluating the implementation.

\subsection{Data Collection and Analysis}

Semi-structured interviews with pre-service teachers were conducted by using the prepared interview form. A statement was made that all kinds of confidentiality will be complied with regarding the interviews held to the pre-service teachers. The interviews were conducted face-to-face and voice-recorded with the mobile phone for analysis.

The content analysis method was used in the analysis of collected data. Voice recordings created were transcribed. After, the answers given to each question were examined in detail and similar answers were appropriately coded.

\section{Results}

Findings from the study were organized in the main categories of data collection. At the same time, some pre-service teachers' visuals about flower care that they had carried out in 9 weeks were given.

\subsection{Findings of "Previous Experiences" Category}

When pre-service teachers were asked if they had been doing flower care in their homes before, some of them stated that their mother or another family member raised flowers at home, but that they were not experienced in this matter. Some of them stated that they did not grow flowers in the house but they planted vegetables and fruits in the garden of their houses. In this regard, the P8 pre-service teacher said, "We live in Konya, we grow trees, vegetables and fruits in the garden of our home, but not flowers, I am helping the housework. We also work on the fields in the summer, harvest wheat and barley. I also worked in the seed screening factory. ". Some said that no flowers were grown in their homes and some took care of flowers in the house only when there was no one to look after at home. A pre-service teacher stated that he has flowers and grows flowers in his room regularly. In general, it is seen that the pre-service teachers do not have much experience in growing flowers at home.

Only one of the respondents answered positively to the question of whether previous school or student experiences had any effect on the process of deciding on the seed and providing the seedlings. This pre-service teacher planted Chlorophytum Tuberosum. He stated that he had the same flower at home before and he preferred it because he really liked it. All of the other pre-service teachers stated that their experiences with their schools did not affect their seedling selection process. Some pre-service teachers also stated that they consulted their families on selecting seedling during the process.

Most of the pre-service teachers answered to the question of what kind of flower and plants design in their previous schools that they remembered flowers, green plants and trees during their primary school years but not during their secondary and high school years. The P4 pre-service teacher stated his ideas related to the topic by saying "I studied elementary school in Germany, they give importance to these kinds of things. We planted seeds in the class. But there were no flowers inside or outside of the school. There were just some in teachers' room. Our teacher loved flowers a lot. He brought a flower to the class for once. But in secondary and high school nobody brought flowers". One of the pre-service teachers stated that he saw there were flowers inside the building of the university for the first time. The P3 and P8 pre-service teachers stated that they did planting trees activities in the school garden during their student lives.

\subsection{Findings of "Implementation Process" Category}

When the answers to the question of how to decide the type of planting they planted were examined, half of the pre-service teachers stated that they decided with the recommendation of the eldest one in their families. The P6 
pre-service teacher stated his own feelings by saying "I decided to plant Hortensia. I am from Kırklareli, there are a lot of Hortensias in my hometown. We brought Hortensia from there in every visit. I told them that I want a flower that can stay green in all seasons, grow up easily and blossom and then they said Hortensia is appropriate for this project.". Some pre-service teachers stated that they had decided on the flowers according to their easy accessibility, and they made the choice from the existing flowers by going to the shop. Also, a pre-service teacher said that he decided to plant roses since he loved roses. All of the pre-service teachers were asked about the way they provided the tools, seedlings, pots and other materials needed for planting, and answered that they provided all from the shops around the school and shops on the roads. They stated that they preferred easy and cheaper products to reach.

\subsection{Findings of "Education" Category}

All the pre-service teachers answered by stating that all teachers should have knowledge of planting to the question of whether the cultivation of flowers in the school is a need-to-know by every teacher and whether it is something that needs to be applied. Regarding the reasons for this, the pre-service teachers stated that the children should be in touch with the nature, the children who are raised away from the nature may be aggressive, the children should feel the sense of responsibility for the plant care process, the children should get love for plants and animals. Only those teachers who have knowledge in this matter can manage these situations. The $\mathrm{P} 4$ pre-service teacher said "Yes, because, in order to take responsibility and teaching it flowers can be planted. I thought it was difficult but it was not. It can be shown to the children. They learn that the flower needs to be watered every week, they take responsibility, they show love for flowers and they will be happy". The P1 pre-service teacher expressed his thoughts; "Yes, in elementary school children should be in touch with nature, of course they need to know theoretical courses but children who are not in touch with the nature are getting aggressive. I personally experienced this. For example, I grew up in nature. Everywhere was green, we were going out for a picnic, but my brother did not. I can see the difference between us, he is aggressive. Most of personal characteristics of individuals are determined by the environment in which people live. Therefore, being in touch with the nature starts from the primary school. Raising flowers can be a step.".

When asked whether they think that flowers should be raised by teachers and students in school corridors and classrooms; all pre-service teachers have stated that it will be useful. The P3 pre-service teacher said; "The things we call school are usually stone buildings, classrooms, corridors, places that have never been attracted to a student, and are not a place to be, when I look back. The fact that at least flowers or pots etc. are placed in certain areas in order to make the school more attractive for students. ". However, the P1 pre-service teacher stated that the corridors may not be suitable for planting flowers because the students are running in corridors. The $\mathrm{P} 2$ pre-service teacher stated that it is appropriate for universities, but it may not be suitable for young students because they could harm the flowers.

The answer that "If they are physically exhausted, they can get rid of it, they will gain positive energy, they will be happy if they like nature, they will respect for green fields and forest, they will love plant, they will understand how useless concretion is, how important green is to them, they will find spiritual pleasure and peace, empathize their feelings, and acquire the spirit of working together from the social point of view" was given to the question of which aspects of flower growth in the school might be beneficial to elementary school students.

Answers such as "teachers need to be a positive role model in environmental issues, to do planting activities, to do plant care activities inside and outside, to let students watch various videos, to give seminars, to do activities about recycling, to do nature trips, to do activities in order to nurture children's love for animals, to teach some of the courses in nature and to visit museums" were given to the question of what kind of activities can be organized in primary schools in order to give the students environmental awareness.

Whether they will raise flowers in their classrooms when they become teachers were asked. All of the pre-service teachers responded with "yes" or "yes if the conditions are proper". The P5 pre-service teacher said, "Yes, I like flowers, also I want to grow flowers in my classroom. Of course, if the conditions of the classroom are proper. For example, if I go to the East side of my country, I do not know what kind of plants I can grow. But if I can find a suitable flower for that place, why not. In fact, if I go to the east of my country, I can bring different types of plants from my hometown in order to teach my students". The P4 pre-service teacher stated that he could care flowers in his classroom in order to create a positive atmosphere and as a result he could contribute to students' learning.

\subsection{Findings of "Evaluating the Implementation" Category}

In this category, whether the planting activity that was implemented at school was useful for their new teaching experiences was asked. All of the pre-service teachers stated that they benefited from the activity. The P2 pre-service teacher said, "Yes, we need to pay attention to the features of plants whether we can grow or not. If we did not do this activity, I would not have so much love for plants. At least, I have some knowledge about plants now. I know what to do 
about plants. I am thinking of what kind of activities I can do in my class when I become a teacher. I would say that everybody in my class should have a plant, based on the plant care I can make an assessment. In fact, this activity influenced me positively and lead me to think about plants". Additionally, the P3 pre-service teacher said, "This activity activated my hidden feelings about planting. I discovered my talent, love and interest on this field. My awareness of plants raised". The P5 pre-service teacher said, "I think you cannot be a teacher if you only teach lessons. We forget something about humanity. I think I remember it". The P8 pre-service teacher said, "Growing flowers is not like growing vegetables and fruits. It requires to mingle with flowers a lot. I learned this".

Preservice teachers who took the Community Service Practices course from the other sections of primary school teaching department did activities such as going to prison nursery, going to social services and child protection institution, going to a public kindergarten and supporting literacy of Syrian children. Preservice teachers in the study were asked to consider the other activities done by their friends who took Community Service Practices course from the other sections. The question of whether they felt lucky or not was asked to the participants. They stated that they think the other groups did useful activities. In addition, they found themselves lucky to be a part of the project. They added that this activity contributed to their knowledge, they learned many things about plants, and their level of affective awareness improved. Besides, one of the pre-service teachers expressed himself lucky because of the possibility of emotional harm in institutions such as prison nursery and child protection institution.

Pre-service teachers gave various answers to the question about what kind of practices they would like to perform if they organized this course. Going to a prison nursery, going to the child protection institution, supporting literacy education of Syrian children and growing plants at school were some of the answers. The other answers given by the participants were to take part in almshouse, to take role in institutions for children with mental disabilities and children with visual disabilities, and people with Leukemia, and to attend in projects of street animals. The P2 and P5 pre-service teachers gave different answers. The P2 pre-service teacher said, "Considering of a society problem, I can send my students to different regions in the city and want them to research the differences. I can reveal disagreements between social segments. Because the life styles are different, we can see how it reflects society". The P5 pre-service teacher said, "I see a lot in Istanbul. For example, I have been going to the same market for 3 years. I greet the market owner but he never greets, he does not even know my name. Human relations are very weak. For this reason, I would like to have a project that requires students to communicate with people they have never spoken to such as security and janitor".

3.5 Some of the Photographs That Show Implementation Processes of Pre-Service Teachers Related the Flower Care

Figure 1 shows the visuals of flower care done by the P6 pre-service teacher (Hortensia)

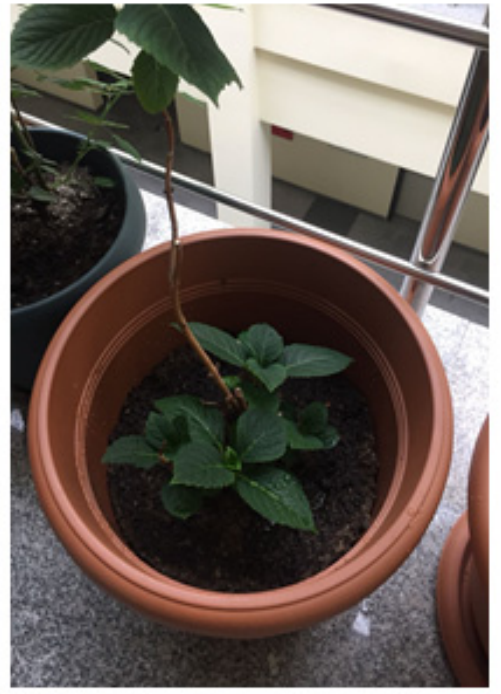

1st week

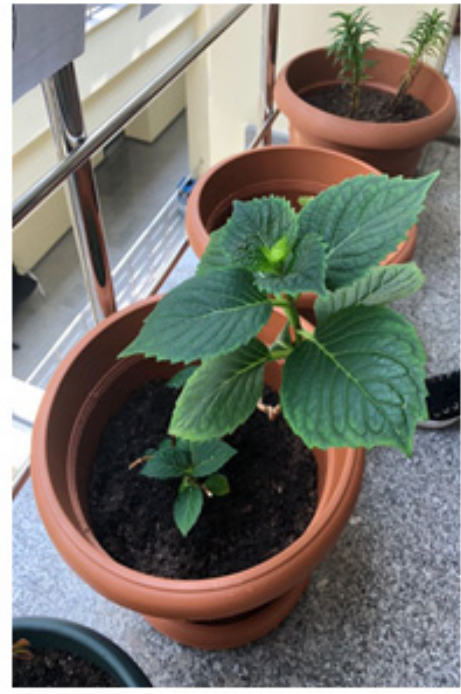

5 th week

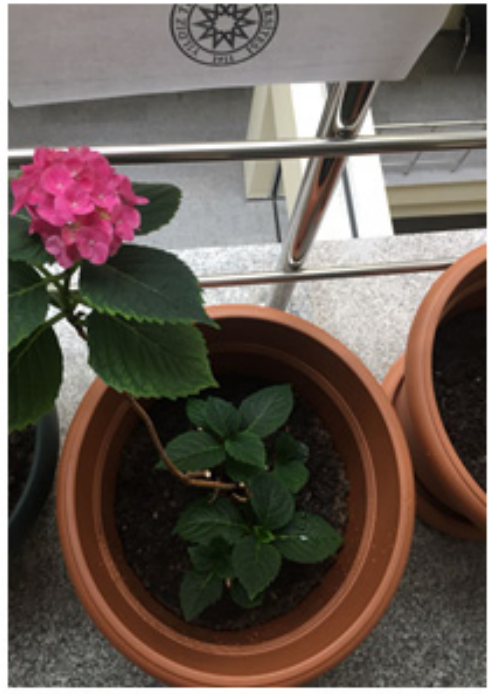

9th week

Figure 1. The Process of Flower Care İmplemented by the P6 Pre-Service Teacher 
The visuals of flower care done by the P7 pre-service teacher is shown in Figure 2 (Geranium)

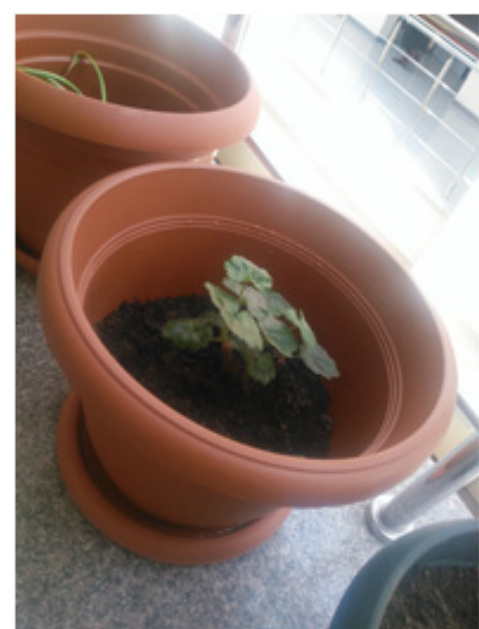

1st week

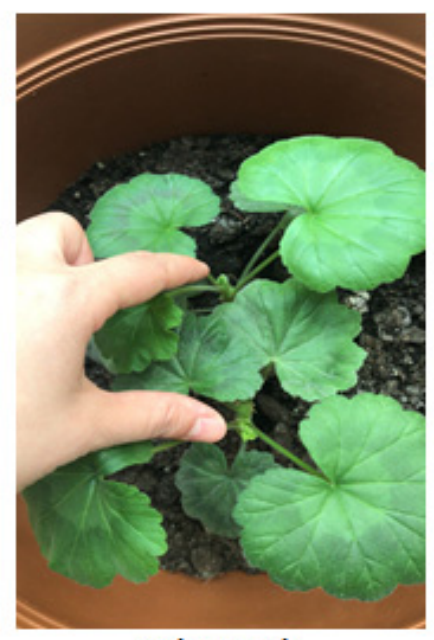

4 th week

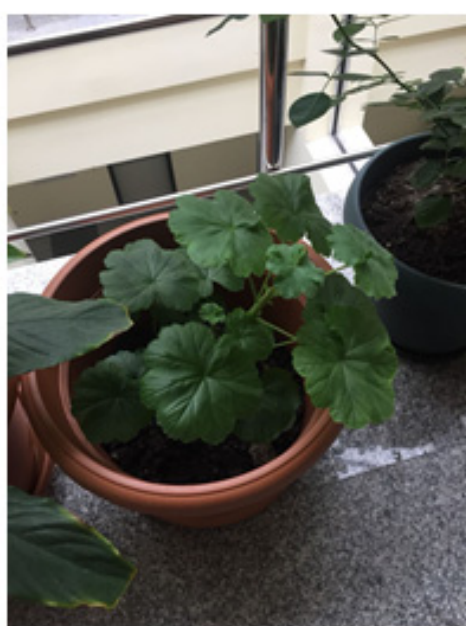

9th week

Figure 2. The Process of Flower Care İmplemented by the P7 Pre-Service Teacher

\section{Conclusion and Discussion}

When the findings of the research about the pre-service teachers' experience about the flower care in their life were evaluated within the scope of the research, it was seen that the they mostly did not have an activity to grow flowers in the past. Based on the findings from the study, there was no difference between male and female pre-service teachers. Family activities have positive effects on teaching processes (Doğan \& Şahin-Taşkın, 2016). However, it can be understood that some of pre-service teachers' parents do flower care activities at home and some of pre-service teachers support their families for flower care regarding of the differences in their families. On the other hand, it has been reported that some of pre-service teachers' families do not do any activities about flower care. It has been observed that some pre-service teachers did not participate in any study about plant care, regardless of the activity at home. It has been observed that the teacher did not make a choice within the scope of their past experiences about the flower species they plan to plant in order to implement the activity. The effect of the fact that the students did not perform a lot of flower care activities in their lives has been observed. The participants have stated that they mostly consulted their elders on flower preference. Apart from the home life of participants, they have little experience with flowers in their previous school life. It has been understood that many of the pre-service teachers do not have any flower care activities in their previous classrooms and schools. Some of the pre-service teachers have witnessed an activity in primary school.

It has been observed that the pre-service teachers exhibited different approaches in selecting the flower to plant. Since the pre-service teachers have insufficient experience with flower planting activities in their past lives, they prefer flowers that they can reach easily. However, the pre-service teachers who performed flower care with their family in the past preferred a flower that was planted in their homes before and that was pleasing to their eyes. It has been observed that the pre-service teachers supplied the other tools necessary for planting activities from the markets that provide cheap shopping opportunities in the immediate vicinity of the school and their home.

All pre-service teachers who participated in the study have revealed the idea that flower planting and care activities are necessary apart from educational events. It is very important to diversify the class activities according to the students (Doğan \& Şahin-Taşkın, 2018). When the pre-service teachers ' views on this issue were examined, it has been seen that this activity would be beneficial for primary school students to be involved in nature, to be responsible, to gain awareness of nature and have love for nature. In addition to the in-class flower growing activities, the idea that this activity can be beneficial throughout the school has become prominent. Similar findings were obtained from Mayer-Smih et. al. (2006) and Enderlin and Osborne (1991) studies. The colorless structure of the schools can be dominated by well-kept flowers and children can be more intertwined with the nature. In addition, it has been observed that the pre-service teachers have taken a wide perspective on the other benefits that flower growing can provide to the students. When the findings are evaluated, they have stated that flower growing will contribute to the development of 
the students in terms of personal, psychological and social aspects. Also, the findings of Klemmer et al. (2005) and McArthur et al. (2010)'s studies support this idea. Moreover, the pre-service teachers stated that there is an important role of teachers in raising environmental awareness for primary school students. It is important for the teacher to form a role model for nature awareness and other natural activities to direct the students in this process apart from flower growing activity. In this context, it has been seen that pre-service teachers want to perform flower growing activities in their teaching profession.

In general, the experience gained after the 10-week implementation by the pre-service teachers has been shown to provide motivation in terms of flower growing activities in their teaching life, classes and schools. However, compared to other activities carried out within the scope of community service practices, it has been observed that it is considered as an interesting, enjoyable and useful work for pre-service teachers as well as for their teaching lives. In addition, it appears that the pre-service teachers need to diversify their community service activities. It is important to establish a unit working within the faculties of education in order to bring these practices into a more systematic way.

\section{References}

Astuti, F. B., Sumarwan, U., \& Qayim, I. (2016). The Role of Student Engagement in the Success of Study of Scholarship Awardee Students of Bogor Agricultural University, Indonesia. Journal of Education and e-Learning Research, 3(3), 106-114. https://doi.org/10.20448/journal.509/2016.3.3/509.3.106.114

Çevre Kanunu. (1983). Kanun Numarası: 2872, Kabul Tarihi: 09.08.1983.

Doğan, M. F., \& Şahin-Taşkın, Ç. (2016). Öğrencilerin Öz-Düzenlemeli Öğrenme Becerilerinin Gelişiminde Anne-Babaların Rolü. International Journal of Curriculum and Instructional Studies, 6(12), 1-18.

Doğan, M. F., \& Şahin-Taşkın, Ç. (2018). Turkish Adaptation of Children's Perceived Use of Self-regulated Learning Inventory. Educational Research and Reviews, 13(10), 375-381.

Elma, C., Kesten, A., Kıroglu, K., Uzun, E. M., Dicle, A. N., \& Palavan, Ö. (2010). Öğretmen adaylarının topluma hizmet uygulamaları dersine ilişkin algıları. Kuram ve Uygulamada Eğitim Yönetimi, 16(2), 231-252.

Enderlin, K. J., \& Osborne, E. W. (1991). Achievement and retention of middle school science students in a laboratory oriented agriculture plant science unit of study. Paper presented at the Central States 45th Annual Research Conference in Agricultural Education, Springfield, IL.

Erten, S. (2012). Türk ve Azeri Öğretmen Adaylarında Çevre Bilinci. Eğitim ve Bilim, 37, 88-99.

Esia-Donkoh, K., \& Bafoe, S. (2018). Instructional Supervisory Practices of Headteachers and Teacher Motivation in Public Basic Schools in Anomabo Education Circuit. Journal of Education and e-Learning Research, 5(1), 43-50.

Hatcher, J. A., \& Erasmus, M. A. (2008). Service-learning in the United States and South Africa: A comparative analysis informed by John Dewey and Julius Nyerere, Michigan.

Keleş, R., Hamamcı, C., \& Çoban, A. (2009). Çevre Politikası (6th ed.). Ankara: İmge Kitabevi.

Klemmer, C. D., Waliczek, T.M., \& Zajicek, J. M. (2005). Growing minds: The effect of a school gardening program on the science achievement of elementary students. Hort Technology, 15(3), 448-452.

Mayer-Smith, J., Bartosh, O., \& Peterat, L. (2007). Teaming children and elders to grow food and environmental consciousness. Applied Environmental Education and Communication, 6(1), 77-85. https://doi.org/10.1080/15330150701319529

Mcarthur, J., Hill, W., Trammel, G., \& Morris, C. (2010). Gardening with youth as a means of developing Science, work and life skills. Children, Youth and Environment, 1, 301-317.

Titlebaum, P., Williamson, G., Daprano, C., Baer, J., \& Brahler, J. (2004). An annotated history of service learning. Dayton, OH: University of Dayton. Available at Learn and Serve America's National Service-Learning Clearinghouse.

Yıldırım, A., \& Şimşek, H. (2011). Sosyal bilimlerde nitel araştırma yöntemleri (8th ed.). Ankara: Seçkin Yayıncılık. 